\title{
高齢者の自伝的記憶の安定性に影響する要因に関する縦断的研究
}

一感情価, 認知機能の低下, 主観的余命, 精神的健康に着目して一

増本康平

(島根大学 法文学部)

key words : 自伝的記憶, 情動, 加齢, 縦断的研究

高齢期は健康の喪失，配偶者や友人等の人間関係の喪失, 定年による社会的役割の喪失というような様々な喪失体験を 経験する時期である。しかしこのようなストレスフルな時期 においても，高齢者の主観的幸福感は若年者と比較して差が なく, むしろ気分 (情動) は若年者よりも安定していること が報告されており，これは「エイジング・パラドクス」と呼 ばれている。このパラドクスを説明する理論に社会情動的選 択性理論がある（Carstensen, 2006）。この理論は，高齢になり 残された時間が限られていると知覚する高齢者は, 情動調整 に動機づけられるというものである。この理論の裏付けとし て, 最近の欧米の研究は, 若年者でみられる注意や記憶にお けるネガティヴィティ・バイアス（ネガティヴ優位性）が高 齢者ではみられず，加齢とともにポジティヴな情報に注意を 向けその記憶が高まるポジティヴ優位性を報告している（増 本・上野, 2009)。しかしながら, 情動調整や人生の意味付け に重要な役割を担う自伝的記憶を指標としてポジティヴ優位 性を検討した増本ら（2009）の研究では，大学生と高齢者で 想起された自伝的記憶の感情価に差がみられず，高齢者では むしろ年齢とともにネガティヴな出来事を想起する傾向にあ った。ただし，ポジテイヴ優位性の生起は年齢（時間経過） に依存すると考えられるため, 大学生と高齢者の横断的な比 較だけでポジティヴ優位性がみられないと結論づけることは できない。そこで本研究では, 増本ら（2009）の研究に参加 した高齢者を対象に，1 年後もう一度，過去の重要な出来事 の想起を求め, 繰り返して想起される出来事にその出来事に 伴う感情価が影響しているかどうか縦断的に検討することを 目的とした。また，ポジティヴな自伝的記憶の想起に影響す ると考えられる要因を探索的に検討した。

\section{方 法}

実験参加者: 健常高齢者 42 名 (年齢; Mean=72.57, range $=63-85$ )。 自伝的記憶課題：これまでの人生の中で，良かったこと悪か つたことに関係なく重要な出来事を 10 分間でできるだけ想 起させ，その内容の記述を求めた。想起内容を実験者に知ら れたくない場合は，参加者本人にだけ想起内容が分かるよう に記述するよう教示した。想起後, それぞれの項目に対して 非常に良い思い出 $: 7$ 点から非常に嫌な思い出; 1 点のどれに 当てはまるか評価を求めた。

認知機能 : ワーキングメモリ（WAIS-3; 算数・数唱・語音整 列）処理速度（WAIS-3; 符号・記号探し）を実施した。

主観的余命：あと何年生きられると思うかについて，回答を 求めた。

精神的健康: 抑うつ状態を測定する尺度である CES-D を実施 した。

これらの指標については, 1 年の間隔をおいて 2 度測定した。

\section{結果及び考察}

2 度の想起によって得られた自伝的記憶を感情価によって ポジティヴとネガティヴにわけ，想起された出来事を経験し た年齢によって想起個数をプロットしたものが Fig.1である。 年齢×感情価の 2 要因分散分析を行った結果，年齢の主効果 $(\mathrm{F}(5,205)=3.11, \mathrm{p}<.01)$ ，感情価の主効果 $(\mathrm{F}(1,41)=11.76$, $\mathrm{p}<.001)$ が有意であり, ポジティヴな出来事の想起個数がネガ ティヴよりも多く, 10 歳未満の出来事が，10 代の出来事より も想起されにくいことが明らかとなった。また，交互作用が 有為傾向であったので $(\mathrm{F}(5,205)=2.02, \mathrm{p}=.08)$, 多重比較を行 つた結果， 20 代，30 代，40 代のポジティヴな出来事が多く 想起されることが示された。

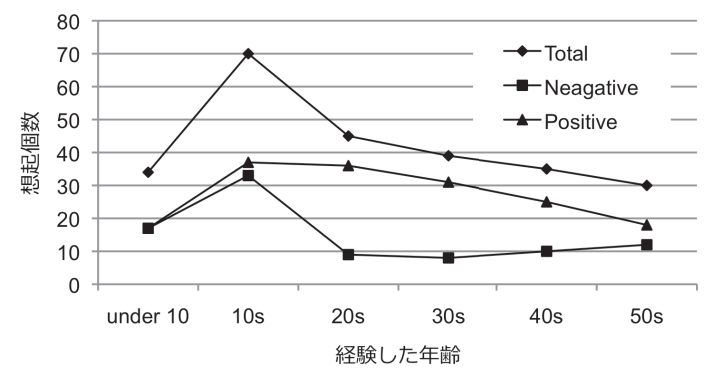

Fig.1 感情価別に見た経験時年齡ごとの想起個数

Fig.2 は感情価別にみた一致率を示したものである。一致率 は 2 度繰り返して想起された出来事の個数を 1 回目に想起さ れた個数で除し た值である。直 接確率検定を実 施した結果，ポ ジティヴよりも ネガティヴな出 来事の一致率が 高いことが示さ

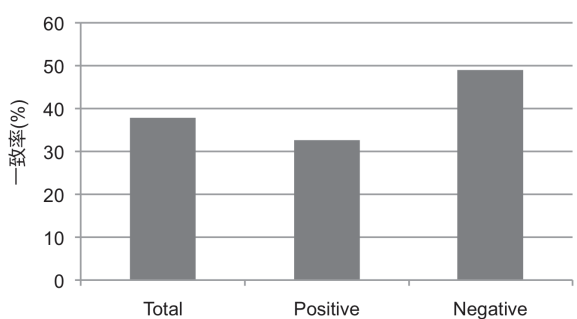

Fig.2 感情価別にみた想起内容の一致率
れた。つまり，ネガティヴな出来事は高齢者でも反復して想 起されることをこの結果は示している。

対象者ごとに想起された自伝的記憶の感情価の平均を算出 し, 2 快目の想起の感情価の平均から 1 回目の想起の感情価 の平均を引いたものを自伝的記憶の感情価変化量とし, 年齢, 認知機能, 主観的余命, 精神的健康との相関分析を行った。 その結果, 年齢, 精神的健康と認知機能の一部に有意な相関 がみられ, 年齢, 抑うつ得点, 認知機能の高い高齢者はネガ ティヴな自伝的記憶を想起する傾向が示された。

繰り返し想起される重要な出来事にポジティヴ優位性がみ られなかった理由として，文化差の影響，実験方法の違いな どが考えられる。

(MASUMOTO Kouhei) 